\title{
Effect of organic manuaring and inorganic fertilization on soil health and crop yield in soybean (Glycinc max L.) onion (Allium cepa) cropping system
}

SHAIKH MEHRAJ, SYED JAVED JANI AND S. D. MORE

MEMBERS OF RESEARCH FORUM:

Corresponding author :

SHAIKH MEHRAJ, Department of

Soil Science And Agricultural

Chemistry, Vasantrao Naik

Marathwada Agricultural University,

PARBHANI (M.S.) INDIA

Co-authors :

SYED JAVED JANI AND S.D.

MORE, Department of Soil Science

And Agricultural Chemistry,

Vasantrao Naik Marathwada

Agricultural University, PARBHANI

(M.S.) INDIA

\section{Summary}

Received : 04.05.2017; Revised : 19.11.2017; Accepted : 28.11.2017

The field experiments were carried out continuously for two years, at cropping system research farm, at Vasantrao Naik Marathwada Agricultural University, Parbhani to study the effect of organic and inorganic on soil health and crop yield of soybean (Glycin max)- onion (Allium/ cepa) Kharif and summer season. The experiments were conducted in Randomized Block Design with seven treatments. Among the different combinations of the tow application of $50 \% \mathrm{~N}$ through $\mathrm{FYM}+$ inorganic sources of micro nutrients $\left(\mathrm{T}_{1}\right)$ recorded significantly beneficial effect on crop yield of soybean onion cropping system. The porosity, infiltration rate, soil $\mathrm{pH}$, electrical conductivity, calcium carbonate and organic carbon observed improved with application of FYM + vcrmicompost + Neem seed cake $\left(\mathrm{T}_{2}\right)$ as an treatments.

Key words : Cropping system, Organic, Inorganic, Soil health, Soybean, Onion

How to cite this article : Mehraj, Shaikh, Jani, Syed Javed and More, S.D. (2017). Effect of organic manuaring and inorganic fertilization on soil health and crop yield in soybean (Glycinc max L.) onion (Allium cepa) cropping system. Asian J. Soil Sci., 12 (2) : 331-337 : DOI : 10.15740/HAS/AJSS/12.2/ 331-337. 